\title{
СОЦІАЛЬНИЙ ЗАХИСТ ДИТИНСТВА В УКРАЇНІ: НОРМАТИВНО-ПРАВОВЕ ЗАБЕЗПЕЧЕННЯ ТА СУЧАСНИЙ СТАН (НА ПРИКЛАДІ МИКОЛАЇВСЬКОЇ ОБЛАСТІ)
}

Шульга A.A., канд. наук з держ. упр, старший викладач, Інститут державного управління, Чорноморський національний університет імені Петра Могили, м. Миколаїв, Україна.

Суріна Н.A., провідний спеціаліст служби у справах дітей Миколаївської обласної державної адміністрації, м. Миколаїв,Україна.

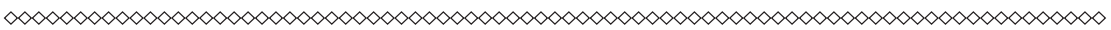

У статті проаналізовано нормативно-правове забезпечення соиіального захисту дитинства в Украӥні, окреслено сучасний його стан (на прикладі Миколаӥвської області), виявлено існуючі проблеми у досліджуваній сфері та запропоновано способи їх вирішення. На початку статті визначено сутність поняття «соиіальний захист» та «соиіальний захист дитинства», наведено різні точки зору вчених на тлумачення циих двох термінів. Основна частина статті присвячена характеристиці становлення системи соціального захисту дитинства та ї̈ нормативно-правового забезпечення. Встановлено, щзо за роки незалежності Украӥни у вирішенні питань соціального захисту дітей ратифіковано низку міжнародних нормативно-правових актів, прийнято векторні вітчизняні закони та інші правові документи, вивчається та застосовується краший іноземний досвід розвинутих крайн світу в побудові сучасної національної системи охорони дитинства тощо. Також вжито суттєвих заходів щодо запровадження в краӥні проактивної соціальної політики стосовно родин, які виховують 618 
дітей. При ичьому з'ясовано, щяо наразі вітчизняна система соиіального захисту дітей не відповідає всім потребам населення краӥни та повною мірою не виконує взяті на себе зобов'язання, спрямовані на забезпечення соціально-правових гарантій прав дітей. Проаналізовано систему закладів інституційного догляду та виховання дітей, а також досліджено розподіл дітей за віком, за терміном перебування у закладах по їх догляду в Миколаївській області тощо. Встановлено, щзо деінституціалізація має на меті запровадження змін у системі захисту дитинства, орієнтованих передусім на збереження та підтримку сім' $і$, якнайкраще забезпечення прав та інтересів дітей. Така політика є умовою для проведення реформ, які спрямовані на зменшення рівня сирітства в країні. У підсумку зазначено, щзо комплексна реалізація запропонованих у статті заходів сприятиме вирішенню існуючих проблем у вітчизняній системі соціального захисту дитинства, координації і спрямуванню дій усіх суб'єктів сочіальної роботи на раннє виявлення сімейного неблагополуччя, надання родинам із дітьми комплексної підтримки і допомоги в подоланні складних життєвих обставин.

Ключові слова: соиіальний захист дитинства, соичіальна послуга, інтернатний заклад, інституційний догляд, складні життеві обставини.

Постановка проблеми у загальному вигляді. Всебічний i гармонійний розвиток дитини, створення належних умов для реалізації та захисту іiі прав і свобод - один із основних пріоритетів будь-якої сучасної демократично-правової країни світу. В Україні захист прав дітей та забезпечення їх благополуччя $€$ загальнодержавною стратегічною ціллю, що пояснюється визначальною роллю молодого покоління у гарантуванні подальшої життєздатності суспільства та прогнозуванні його успішного розвитку. Так, у ст. 51-52 Конституції України закріплено, що «сім’я, дитинство, материнство і батьківство охороняються державою, a утримання та виховання дітей-сиріт i дітей, позбавлених батьківського піклування покладається на державу [6].

Сьогодні в умовах публічно-управлінських і соціальноISSN 2616-6216. Publ. upr. reg. rozvit. 2020, 8: 618-653 
«Public Administration and Regional Development»

https://pard.mk.ua/index.php/journal

економічних перетворень та наявності військового конфлікту на сході країни, проблема соціального захисту дитинства набуває особливої гостроти. Адже діти - це своєрідні соціальні індикатори, які визначають рівень добробуту населення та чутливо реагують на всі зміни, що відбуваються в державі, проте самостійно не можуть на них впливати. Відповідно приділяється увага створенню належних умов для їх фізичного, інтелектуального й духовного розвитку, повноцінної життєдіяльності.

Однак, Україна настільки поглинула у безкінечний процес реформування різних суспільних сфер, вирішення військового питання із Російською Федерацією та іiі інтеграції у Свропейське співтовариство, що соціальний захист дітей просто відійшов назадній план. Більше того, ті реформаторські зміни, що запроваджуються в нашій державі лише посилюють безправ'я дітей, особливо окремих їх категорій (діти-сиріти, діти з особливими потребами тощо). На жаль, взятий Україною курс розвитку направлений на досягнення економічних і міжнародно-політичних звершень, ніж на покращення соціального положення незахищених верст населення, особливо дітей (існуюча система соціального захисту дітей не в змозі повною мірою забезпечити реалізацію їх прав та належний розвиток).

Аналіз досліджень і публікацій. Значний внесок у дослідження соціального захисту дитинства зробили як зарубіжні, так i вітчизняні науковці, серед яких можна назвати: В. Борденюка, Г. Бребана, В. Бабкіна, Ж. Веделя, I. Грицяка, В. Бебика, О. Бориславську, Г. Атаманчука, Б. Гаєвського, А. Коваленко, Р. Колишко, А. Матвієнка, С. Махину, I. Трофимову, Б. Гурне, С. Дубенка, В. Князєва, В. Лугового, І. Надольного, Н. Нижника, Ю. Пахомова, О. Петришина, Г. Райта, С. Рябову, О. Скрипнюка, В. Цвєткова, В. Скуратівського, М. Стрельбицького, В. Шаповала, Г. Щокіна та ін. Безпосередньо питання державної політики щодо захисту прав дітей, їх соціального благополуччя досліджували В. Довженко, 3. Кияниця, Ю. Павленко, Л. Волинець, Н. Комарова, Ю. Парамонов. Проте, незважаючи на накопичений досвід та значну кількість наукових праць вітчизняних й іноземних дослідників, існує ряд невирішених теоретичних і практичних питань стосовно 
Сочіальний захист дитинства в Україні: нормативно-правове забезпечення та сучасний стан (на прикладі Миколаӥвської області)

вітчизняної системи соціального захисту дитинства, зокрема питання іiі модернізації в умовах сучасних публічно-управлінських перетворень.

Формулювання цілей статті (постановка завдання). Метою цієї статті $€$ аналіз нормативно-правового забезпечення соціального захисту дитинства в Україні та окреслення сучасного його стану (на прикладі Миколаївської області).

Виклад основного матеріалу дослідження. Соціальний захист $є$ однією із невід'ємних складових політики держави, відповідальної за добробут, розвиток і безпеку своїх громадян. Саме соціальний захист $є$ показником цивілізаційного розвитку будь-якого суспільства.

Поява та широке застосування терміну «соціальний захист» було спричинено кардинальними змінами соціальної політики іноземних країн після Другої світової війни, яка стала своєрідним поштовхом у розумінні необхідності розвитку і систематизації різноманітних інститутів соціальної сфери. Поширеною є думка, що виникнення поняття «соціальний захист» прямо пов’ язано із прийняттям у 1935 p. закону США про соціальний захист (Social Security Act), який Президент США Франклін Рузвельт визначив «наріжним каменем у системі, яка будується зараз, але у жодному разі не завершується» [18, с. 102]. Однак, є й інші точки зору щодо виникнення даного поняття. Як зазначає Гай Перрін, попри те, що цей термін уперше вжито у США, концепція системи соціального захисту в повному обсязі була втілена у новозеландському законодавстві в 1938 р. [10, с. 399]. Н.I. Болотіна ж стверджує, що пріоритет тут належить Росії - 31 жовтня 1918 р. Тимчасовий уряд затвердив Положення про соціальне забезпечення трудящих [2, с. 37]. У будь-якому разі можна говорити, що від 30-х років XX ст. термін «social security» став загальновживаним. При цьому термін «security» вживається у значенні «безпека», «охорона», «захист», «забезпечення», «гарантування».

1. На сьогодні поняття «соціальний захист»є одним із найбільш дискусійних категорій права соціального забезпечення. Розмаїття підходів стосовно вказаного терміну зумовлено кількома ISSN 2616-6216. Publ. upr. reg. rozvit. 2020, 8: 618-653 
чинниками:

2. певна новизна цієї категорії для національної науки і практики;

3. актуальність питань, пов'язаних із соціальним захистом населення;

4. відсутність уніфікованого нормативного визначення терміну $[4$, c. 435$]$.

У широкому розумінні під соціальним захистом розуміють діяльність держави, спрямовану на забезпечення процесу становлення повноцінної особистості, виявлення і нейтралізацію негативних факторів, що впливають на неї, а також створення умов для iї самовизначення й утвердження в житті. У вузькому сенсі - це сукупність законодавчо закріплених економічних і правових гарантій, що забезпечують дотримання найважливіших соціальних прав громадян і досягнення соціально-прийнятного рівня життя [8, с. 3].

В цілому поняття соціального захисту охоплює діяльність держави, органів місцевого самоврядування, громадських організацій та підприємств щодо створення сприятливого для людей навколишнього середовища, охорони материнства i дитинства, надання допомоги родинам, охорони здоров'я громадян, їх професійної підготовки, забезпечення зайнятості населення, охорони праці, регулювання заробітної плати і доходів населення, забезпечення громадян житлом та регулювання їх права власності, матеріального обслуговування i забезпечення непрацездатних громадян й інших нужденних у соціальній підтримці [14, с. 8].

Своєрідне визначення соціального захисту наведено в американській енциклопедії - «соціальний захист, у загальному розумінні цього поняття, означає безпеку й свободу від страху» [18, с. 103]. Натомість у російській економічній енциклопедії 1999 р. під соціальним захистом розуміється «важлива функція держави по забезпеченню основних соціальних прав людини на основі міжнародних і національних норм» [1, с. 207].

Міжнародна організації праці трактує соціальний захист як 
захист, який суспільство забезпечує своїм членам за допомогою набору суспільних заходів від економічних i соціальних лих, що зумовлені припиненням або істотним зниженням рівня працездатності в результаті хвороби, пологів, виробничих нещасних випадків, безробіття, інвалідності, старості і смерті; забезпечення медичної допомоги, надання субсидій сім'ям із дітьми [3].

Більшість вітчизняних науковців наголошують на тому, що «соціальний захист є однією із функцій держави та являє собою комплекс заходів матеріальної підтримки непрацездатних і найменш захищених громадян» [16, с. 10].

Якщо говорити про нормативне закріплення досліджуваного поняття, то у вітчизняному законодавстві воно відсутнє. Ті законодавчі акти, що стосуються соціального захисту населення розкривають виключно зміст поняття соціального захисту тієї чи іншої категорії осіб. Так, наприклад, у ст. 1 Закону України «Про соціальний i правовий захист військовослужбовців та членів їх сімей» від 20 грудня 1991 р. № 2011-XII зазначено, що «соціальний захист військовослужбовців - це діяльність (функція) держави, спрямована на встановлення системи правових i соціальних гарантій, що забезпечують реалізацію конституційних прав і свобод, задоволення матеріальних і духовних потреб військовослужбовців відповідно до особливого виду їх службової діяльності, статусу в суспільстві, підтримання соціальної стабільності у військовому середовищі. Це право на забезпечення їх у разі повної, часткової або тимчасової втрати працездатності, втрати годувальника, безробіття з незалежних від них обставин, у старості, а також в інших випадках, передбачених законом» [29].

Розглянувши різні наукові погляди на зміст поняття «соціальний захист», можна узагальнити, що соціальний захист дитинства $є$ однією із функцій держави, сутність якої полягає у встановленні системи і соціально-правових гарантій, що забезпечують реалізацію конституційних прав і свобод, задоволення матеріальних і духовних потреб осіб, котрі не досягли 18-річного віку відповідно до особливого їх становища та статусу в суспільстві.

Ідея захисту прав дитини була предметом дискусії державних 
«Public Administration and Regional Development»

https://pard.mk.ua/index.php/journal

діячів протягом багатьох століть, проте активізувався процес охорони дитинства тільки в XIX ст. Безпосередньо права дитини отримали міжнародне правове визнання завдяки Енглантайн Джебб, яка створила фонд для надання допомоги тисячам нужденних дітей, що згодом був реорганізований у Міжнародний союз захисту дітей. Саме цей союз підготував проект Женевської декларації, ухваленої Лігою Націй у 1923 р. - першого міжнародного документу, в якому порушувалася проблема захисту прав дитини [7].

У 1918 р. радянська влада проголосила всіх дітлахів державними та почала шукати можливі форми влаштування безпритульних дітей і дітей-сиріт. У результаті вже в 1920 р. було прийнято Декларацію про соціальне виховання дітей, відповідно до якої запроваджувалася система соціального виховання, що мала охоплювати малечу від народження до 15 років. Основною і єдиною формою соціального виховання визнавався дитячий будинок. На той час у процесі запровадження нової системи охорони дитинства впливовими були теорії А. Макаренка, який вірив у колективне виховання [9, с. 209300]. Однак, спроби практичної реалізації цих теорій були зруйновані реальним життям - після Першої світової війни багато дітей стали сиротами, а кількість безпритульної дітвори сягала майже 8 мільйонів. I лише у другій половині 20 -х років радянській владі вдалось подолати проблему безпритульності дітей, їх жебрацтва i злочинності, в результаті чого кількість дітлахів, які виховувалися у спеціальних закладах значно зменшилась.

Після закінчення Другої світової війни патронатне виховання знову було замінене на інституційне з метою повномасштабного залучення жінок до праці та їх звільнення від домашніх обов'язків. Так, у післявоєнний період було відкрито більше 650 нових дитячих будинків, в котрих мешкало понад 600 тис. дітей, більшість 3 яких мали батьків.

У 1960-ті роки в Радянському Союзі було запроваджено нову форму інституційної опіки дітей - «школа-інтернат», яка передбачала здійснення повного циклу навчально-виховного процесу дітлахів в одному закладі та їх ізоляцію від зовнішнього світу. На той час певний інноваційний прорив у ставленні 624 Isue DOI: 10.34132/pard 
Сочіальний захист дитинства в Україні: нормативно-правове забезпечення та сучасний стан (на прикладі Миколаӥвської області)

до дитини та сім’ї було здійснено В. Сухомлинським, який проголосив дитину найвищою цінністю та відводив ключову роль саме родині і сімейному вихованню у становленні малюка як окремої особистості [15, с. 149]. Та вже у 1970-80-ті роки для радянських громадян традиційними вважались послуги 3 під-

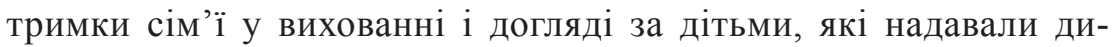
тячі садочки, групи продовженого дня у школах, позашкільні заклади, оздоровчі піонерські табори, спортивні секції, клуби за місцем проживання, інтернатні установи тощо. Допомогу у наданні таких послуг також здійснювали профспілкові комітети, комсомольські та піонерські організації.

Після повалу радянської влади більшість громадян України опинилися у складній економічній ситуації, що характеризувалася тотальним безробіттям і масовою трудовою міграцією, бідністю, зростанням рівня злочинності, а також загостренням проблем алкоголізму і наркоманії. Це все позначилося на найменш захищеній верстві населення - дітях. Почали масово закриватися дитячі садочки, позашкільні заклади, скорочувалася кількість вихователів і педагогів, у школах зменшувалась кількість груп продовженого дня. Водночас значно розширилась мережа інтернатних закладів, до яких, окрім дітей-сиріт, почали приймати дітей, чиї батьки 3 тих чи інших причин не могли забезпечити їх першочергові потреби. У свою чергу, обмежене фінансування, застарілі форми і методи роботи були причиною втеч дітей з інтернатів [23, с. 56]. У результаті в незалежній Україні виникла потреба в побудові нової національної системи охорони дитинства, яка б забезпечувала високі стандарти соціального захисту дітей.

Першим кроком у цьому напряму стало підписання Україною Конвенції ООН про права дитини у 1991 р. Далі, упродовж кількох років, з урахуванням положень цієї Конвенції, була прийнята низька важливих Законів: «Про освіту» від 23 травня 1991 р.; «Основи законодавства України про охорону здоров'я» від 19 листопада 1992 р.; «Про державну допомогу сім’ям 3 дітьми» від 21 листопада 1992 р.; «Про фізичну культуру і спорт» від 24 грудня 1993 р. Окрім того, утворено мережу центрів соціальних служб для молоді як ISSN 2616-6216. Publ. upr. reg. rozvit. 2020, 8: 618-653 625 
«Public Administration and Regional Development»

https://pard.mk.ua/index.php/journal

соціальних інституцій, котрі відповідали за соціальну роботу 3 підлітками та молоддю. А в 1995 р., на основі Закону України «Про органи і служби у справах дітей та спеціальні установи для дітей» від 24 січня 1995 р. № 20/95-ВР, створено перші окремі державні інститути - служби у справах неповнолітніх, на які покладалося вирішення питання соціально-правового захисту дітей, подолання дитячої бездоглядності, безпритульності та профілактики дитячої злочинності [25].

На початку 1996 р. 3 метою координації дій, пов’язаних iз виконанням Конвенції ООН про права дитини і Всесвітньої декларації про виживання, захист і розвиток дітей було видано Указ Президента України «Про національну програму «Діти України»»» № 63/96. Призначення цієї програми полягало у забезпеченні прав кожної дитини народитися здоровою, вижити і мати умови для всебічного розвитку, бути надійно, соціально і психологічно захищеною [19].

У 1996 р. започаткувалася підготовка Щорічних державних доповідей про становище дітей в Україні. В цьому ж році було створено Міністерство у справах сім’і та молоді, а в 2000 р. Міжвідомчу комісію з питань охорони дитинства. У цей же період ухвалюється ряд нових Законів України: «Про прожитковий мінімум» від 15 липня 1997 р.; «Про професійно-технічну освіту» від 10 лютого 1998 р.; «Про молодіжні та дитячі громадські організації» від 1 грудня 1998 р.; «Про загальну середню освіту» від 13 травня 1999 р.; «Про державну соціальну допомогу малозабезпеченим сім’ям» від 1 червня 2000 р.; «Про позашкільну освіту» від 22 червня 2000 р.; «Про державні соціальні стандарти та державні соціальні гарантії» від 5 жовтня 2000 р.; «Про державну соціальну допомогу інвалідам 3 дитинства та дітям-інвалідам» від 16 листопада 2000 р. та ін.

Надалі революційним у національній системі охорони дитинства стало прийняття таких законодавчих актів як:

- Закон України «Про охорону дитинства» від 26 квітня 2001 р. № 2402-III, який «закріплює охорону дитинствав Україніякстратегічний загальнонаціональний пріоритет, що має важливе значення 626 Isue DOI: 10.34132/pard 
Сочіальний захист дитинства в Україні: нормативно-правове забезпечення та сучасний стан (на прикладі Миколаӥвської області)

для забезпечення національної безпеки України, ефективності внутрішньої політики держави, і з метою забезпечення реалізації прав дитини на життя, охорону здоров’я, освіту, соціальний захист, всебічний розвиток та виховання в сімейному оточенні встановлює основні засади державної політики у цій сфері, що грунтуються на забезпеченні найкращих інтересів дитини» [24];

- Закон України «Про соціальну роботу з сім’ями, дітьми та молоддю» від 26 червня 2001 р. № 2558-III, що «визначає організаційні та правові засади соціальної роботи з дітьми, сутність якої полягає в оцінюванні потреб у соціальних послугах сімей, дітей та молоді, плануванні, організації, координації та наданні їм соціальних послуг, державних соціальних допомог, пільг, компенсаційних виплат та іншої соціальної підтримки, а також здійсненні моніторингу надання соціальних послуг» [28];

- Закон України «Про попередження насильства в сім’ї» від 15 листопада 2001 р. № 2789-III - окреслює поняття «насилля» та похідні від нього терміни, визначає органи та установи, на які покладається здійснення заходів 3 попередження насильства в сім’”, а також закріплює організаційно-правові основи попередження такого насильства [27]. На зміну цьому Закону, у 2017 р. було прийнято новий законодавчий акт - «Про запобігання та протидію домашньому насильству», що визначає організаційно-правові засади запобігання та протидії домашньому насильству, основні напрями реалізації державної політики у сфері запобігання та протидії домашньому насильству, спрямовані на захист прав та інтересів осіб, які постраждали від такого насильства [32];

- Сімейний кодекс України від 10 січня 2002 р. № 2947-III окреслює підстави виникнення, зміст особистих немайнових i майнових прав та обов'язків батьків і дітей, усиновлювачів та усиновлених, інших членів сім'̈і та родичів. А також закріплює, що дитина належить до сім’ї своїх батьків і тоді, коли спільно 3 ними не проживає [33];

- Закон України «Про забезпечення організаційно-правових умов соціального захисту дітей-сиріт та дітей, позбавлених батьківського піклування» від 13 січня 2005 р. № 2342-IV, що закріплює «правові, ISSN 2616-6216. Publ. upr. reg. rozvit. 2020, 8: 618-653 
«Public Administration and Regional Development»

https://pard.mk.ua/index.php/journal

організаційні, соціальні засади та гарантії державної підтримки дітей-сиріт та дітей, позбавлених батьківського піклування, а також осіб із їх числа, і $є$ складовою частиною законодавства про охорону дитинства» [30]. Більше того, Закон гарантує, що «державні соціальні стандарти для дітей-сиріт та дітей, позбавлених батьківського піклування, а також осіб із їх числа встановлюються незалежно від того, де така дитина або особа перебуває на утриманні та вихованні, на рівні, не меншому за встановлений прожитковий мінімум для осіб відповідного віку» [30];

- Закон України «Про основи соціального захисту бездомних осіб і безпритульних дітей» від 2 червня 2005 р. № 2623-IV - «визначає загальні засади соціального захисту бездомних осіб і безпритульних дітей, забезпечує правове регулювання відносин у суспільстві, які спрямовані на реалізацію бездомними особами і безпритульними дітьми прав і свобод, передбачених Конституцією та законодавством України, створює умови для діяльності громадських та благодійних організацій, що працюють у сфері соціального захисту населення» [26].

У 2005 р. із виданням Указу Президента України «Про першочергові заходи щодо захисту прав дітей» від 11 липня 2005 р. № 1086/2005 розпочалося реформування державної системи опіки та піклування про дітей. Безпосередньо було:

1. утворено Державний департамент з усиновлення та захисту прав дитини при Міністерстві сім’ї, молоді та спорту України

2. передано функції ведення справ щодо усиновлення, опіки та піклування службам у справах дітей та новоутвореному Департаменту;

3. запроваджено принципово нову модель надання державної соціальної підтримки дітям-сиротам та дітям, позбавленим батьківського піклування, основний принцип якої - «гроші ходять за дитиною» [21].

В 2009 р. прийнято стратегічно важливий документ для захисту дитинства - Закон України «Про загальнодержавну програму «Національний план дій щодо реалізації Конвенції ООН про права дитини» на період до 2016 року» від 5 березня 2009 р. № 1065-VI. 628 
Соціальний захист дитинства в Украӥні: нормативно-правове забезпечення та сучасний стан (на прикладі Миколаївської області)

Метою цієї програми є «забезпечення оптимального функціонування цілісної системи захисту прав дітей в Україні відповідно до вимог Конвенції ООН про права дитини та з урахуванням цілей розвитку, проголошених Декларацією тисячоліття ООН, і стратегії Підсумкового документа Спеціальної сесії в інтересах дітей Генеральної Асамблеї ООН «Світ, сприятливий для дітей»» [31]. Паралельно ліквідовано Державний департамент з усиновлення та захисту прав дитини, Державну соціальну службу для сім’і, дітей та молоді, функції яких передано Міністерству соціальної політики України.

Через два роки в нашій державі було засновано інститут дитячого омбудсмена, необхідність якого обгрунтовувалась такими причинами як: потреба в особливому підході до дітей через особливості їх психічного і фізичного розвитку; практична неможливість дітей самостійно захищати свої права і законні інтереси у зв'язку із відсутністю у них життєвого досвіду та їх залежного становища від дорослих; визначення «світлого» майбутнього будь-якої країни через рівень благополуччя та нормальний розвиток дітей.

Концептуальними засадами роботи омбудсмена визначено:

1. «почути кожну дитину, права якої порушено та зробити все необхідне для їх поновлення;

2. необхідність ведення моніторингу усіх дій та рішень центральних і місцевих органів влади, котрі стосуються прав й інтересів дітей, їх аналіз на відповідність законодавству 3 питань охорони дитинства;

3. внесення всіма без винятку органами влади необхідних змін до чинного законодавства щодо забезпечення прав та інтересів дітей» [22].

Подальшими кардинальними кроками у сфері соціального захисту дитинства стали розробка та реалізація двох Національних стратегій. Перша 3 них - Національна стратегія профілактики соціального сирітства на період до 2020 року, була затверджена Указом Президента України у жовтні 2012 р. «з метою забезпечення реалізації кожною дитиною права на виховання в сім’і, зростання в безпечному сімейному оточенні, підвищення ефективності ISSN 2616-6216. Publ. upr. reg. rozvit. 2020, 8: 618-653 
«Public Administration and Regional Development»

https://pard.mk.ua/index.php/journal

роботи державних органів та органів місцевого самоврядування із запобігання соціальному сирітству, вдосконалення системи надання соціальних послуг дітям і сім'ям 3 дітьми» [20]. Очікуваними результатами від реалізації цієї Стратегії було:

- «організація ефективної діяльності суб'єктів соціальної роботи 3 родинами, дітьми та молоддю щодо раннього виявлення сімей, які входять до групи ризику і можуть опинитися у складних життєвих обставинах, надання їм відповідних соціальних послуг, попередження вилучення дитини з сім’і;

- забезпечення надання якісних соціальних послуг дітям та сім'ям 3 дітьми, які перебувають у складних життєвих обставинах;

- зменшення кількості сімей з дітьми, які перебувають у складних життєвих обставинах, дітей-сиріт та дітей, позбавлених батьківського піклування, котрі виховуються в інтернатних закладах, а також зменшення кількості дітей, які перебувають поза сімейним оточенням;

- створення умов для утвердження в суспільстві сімейних цінностей, виховання відповідального батьківства та запобігання соціальному сирітству» [20].

Розпорядженням уряду у серпні 2017 р. була схвалена друга Національна стратегія реформування системи інституційного догляду та виховання дітей на 2017-2026 роки та план заходів 3 реалізаціїї І етапу, з метою зміни існуючої системи інституційного догляду і виховання дітей, яка не відповідає реальним потребам дітей та сімей 3 дітьми, і створення умов для повноцінного виховання і розвитку дитини в родині [12]. Запроваджені зміни передбачають створення такої системи, яка б забезпечувала догляд і виховання дитини в сімейному або наближеному до сімейного середовищі. Подальша ліквідація відповідних закладів - це наслідок того, що потреба у влаштуванні дітлахів до них буде просто відсутня.

Більшість країн Європи вже пішли цим шляхом. Так, наприклад, Румунія на початку реформування власної системи соціального захисту дитинства у 2001 р. мала 100 тис. дітей, котрі перебували в інтернатних закладах різного типу, а в результаті проведення 
реформи таких дітей нараховувалось вже 18 тис. (-82\%). У Молдові більш 9 тис. дітей мешкало в зазначених закладах (2007р.), а після реформування їх кількість знизилась до 2 тис. (-78\%). Аналогічна ситуація спостерігалася і в Болгарії - до реформи майже 7 тис. дітей були вихованцями різних інтернатів, а після запроваджених змін кількість таких дітей не перевищувало 1,5 тис. (-77\%) [17].

Наразі в Україні 1,5\% дітей перебувають в інтернатах, причинами влаштування яких є соціальні (діти-сироти, діти, котрі позбавлені батьківського піклування, бідність, складні життєві обставини) та медичні показання (інвалідність, розлади психіки). Тоді як в європейських країнах цей показник майже не перевищує 0,5\% (0,1\% - Австрія, Норвегія, 0,5\% - Польща, Болгарія, Румунія, Молдова). Заклади інституційного догляду за дітьми в Європейському Союзі визнано місцями несвободи, в яких мешкає у середньому 6-12 дітей (для порівняння в Україні - 100-300 дітей (по 6-16 дітей у кімнаті)), а радянська інтернатна система, що досі діє в нашій країні, є просто неприйнятною для європейського суспільства [17].

Різні країни світу мають власні традиції становлення і розвитку системи захисту дитинства, більшість 3 яких впроваджують політику деінституалізації, що спрямована на зменшення сирітства, поліпшення механізмів державного регулювання системи опіки та піклування, з обов'язковим урахуванням індивідуальних потреб дітей. До речі, саме скандинавські країни за рівнем соціального забезпечення населення через домінування державної моделі його організації є найбільш соціально орієнтованими у питанні соціального захисту дитинства. Окрім того, сучасні тенденції розвитку іноземних систем соціального захисту чітко прокладають курс на залучення до вирішення проблем дітей недержавних інститутів суспільства, в тому числі шляхом створення і надання податкових пільг для стимулювання неурядових фондів соціального забезпечення. Вважаємо, що саме такі підходи у вирішенні питань соціального захисту дитинства є кардинально новим орієнтиром для України, що можуть бути в подальшому адаптовані до вітчизняних реалій.

Щороку в України виводиться рейтинг областей за рівнем інсти- 
«Public Administration and Regional Development»

https://pard.mk.ua/index.php/journal

туціалізації дітей, відповідно до якого регіони до 1,5\% інституціалізованих дітей мають помірний рівень інституціалізації, 1,5\%-2\% високий рівень та понад 2\% - критичний рівень. У 2019 р. одні із перших місць у цьому рейтингу зайняли Київська (061\%) та Одеська $(0,84 \%)$ області, безпосередньо Миколаївська область посіла передостаннє місце (2,27\%). При цьому середній показник по країні становив - 1,4\%. Це говорить про те, що в Миколаївській області незадовільний рівень інституційного догляду дітей та відповідно їх належного соціального захисту (див. Таблиця 1) [11].

Таблиця 1

\section{Рейтинг регіонів України за рівнем інституціалізації дітей} станом на 1 січня 2019 р.

\begin{tabular}{|c|l|c|}
\hline № & \multicolumn{1}{|c|}{ Область } & Показник (\%) \\
\hline 1 & Киівська & 0,61 \\
\hline 2 & Одеська & 0,84 \\
\hline 3 & Житомирська & 1,04 \\
\hline 4 & Чернівецька & 1,07 \\
\hline 5 & Вінницька & 1,15 \\
\hline 6 & Рівненська & 1,18 \\
\hline 7 & Донецька* & 1,2 \\
\hline 8 & Закарпатська & 1,24 \\
\hline 9 & Львівська & 1,26 \\
\hline 10 & Тернопільська & 1,26 \\
\hline 11 & Івано-Франківська & 1,32 \\
\hline 12 & Луганська* & 1,47 \\
\hline 13 & Харківська & 1,52 \\
\hline 14 & Дніпропетровська & 1,56 \\
\hline 15 & Хмельницька & 1,58 \\
\hline 16 & Сумська & 1,64 \\
\hline 17 & Черкаська & 1,69 \\
\hline 18 & Полтавська & 1,77 \\
\hline 632 & & \\
\hline
\end{tabular}


Сочіальний захист дитинства в Україні: нормативно-правове забезпечення та сучасний стан (на прикладі Миколаӥвської області)

продовження таблиці 1

\begin{tabular}{|c|l|c|}
\hline 19 & Херсонська & 1,83 \\
\hline 20 & Чернігівська & 1,87 \\
\hline 21 & Волинська & 1,89 \\
\hline 22 & Кіровоградська & 1,95 \\
\hline 23 & Миколаївська & 2,27 \\
\hline 24 & Запорізька & 2,43 \\
\hline
\end{tabular}

*Без урахування тимчасово окупованих територій та Автономної Республіки Крим

3 метою усунення проблем у сфері соціального захисту дитинства та покращення соціально-економічного становища дітей, які цього потребують, влада Миколаївщини з урахуванням положень Національної стратегії реформування системи інституційного догляду та виховання дітей на 2017-2026 роки та план заходів 3 реалізації іiі I етапу, розробила відповідний Проект регіонального стратегічного плану дій з реформування системи інституційного догляду та виховання дітей в Миколаївській області на 20192026 роки. Метою цього плану є «послідовне реформування діючої системи забезпечення прав дітей в регіоні та формування такої системи, яка забезпечить право дитини на проживання, догляд і виховання в сім'ї або умовах, максимально наближених до сімейних, на доступ до якісних соціальних, освітніх, медичних послуг» [13]. У процесі реформування кожного закладу по догляду за дітьми планується, по можливості, на їх базі створити інші освітні, медичні, соціальні установи/центри для надання послуг дітям та їх сім'ям, 3 урахуванням потреб місцевих громад, на території яких і будуть розташовуватись такі установи.

Сьогодні система інституційного догляду дітей в Миколаївській області представлена 28 установами, 3 них: 22 (78\%) - це заклади освіти, 4 (14\%) - заклади служб у справах дітей та по 1 закладу системи соціального захисту і системи охорони здоров'я (див. Рис. 1) [13]. 


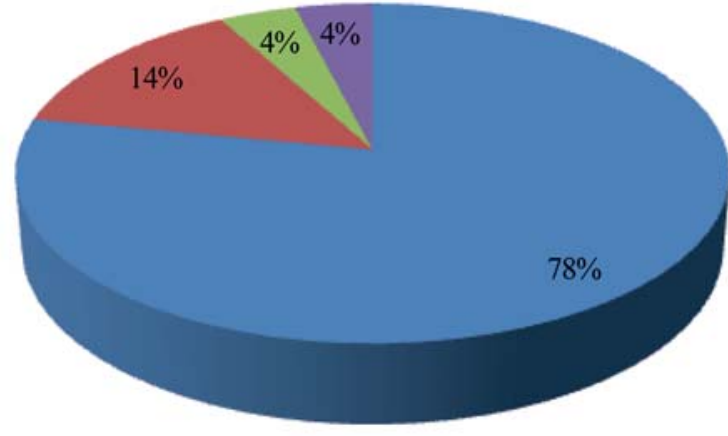

- заклади освіти

заклади служб у

справах дітей

- заклади системи

соціального захисту

заклади системи

охорони здоров'я

Pис. 1. Розподіл закладів по догляду за дітьми за сферами підпорядкування в Миколаївській області у 2019 р. [13]

Безпосередньо до закладів освіти належать:

- спеціальні школи-інтернати - функціонують для дітей, які потребують корекції фізичного та/або розумового розвитку. 311 таких закладів, що функціонують в області, 9 призначені для дітей із інтелектуальними порушеннями (легка розумова відсталість), по одному закладу - для дітей, що мають тяжкі порушення мовлення та слуху;

- загальноосвітні школи-інтернати (7 закладів) - створені для дітей-сиріт, дітей позбавлених батьківського піклування та дітей iз сімей, які перебувають у складних життєвих обставинах i потребують соціальної допомоги (наприклад, важке матеріальне становище родини, особливий режим роботи батьків або важкий стан їх здоров'я);

- санаторні школи-інтернати (4 заклади) - призначенні для дітей iз захворюваннями органів дихання, серцево-судинної системи, хворих на сколіоз та дітей 3 малими і затухаючими формами туберкульозу [13].

Бюджетним спеціалізованим закладом охорони здоров'я $\epsilon$ будинок-дитини, що заснований на спільній власності 634 Isue DOI: $10.34132 /$ pard 
Сочіальний захист дитинства в Україні: нормативно-правове забезпечення та сучасний стан (на прикладі Миколаївської області)

територіальних громад сіл, селищ та міст області, інтереси яких у межах повноважень, визначених чинним законодавством України, представляє Миколаївська обласна рада. У цьому будинку мешкають малюки від народження і до трирічного віку, а діти, котрі мають дефекти розумового чи фізичного розвитку - до 4 років. На даний час у закладі перебуває 127 дітлахів, частина з яких мають батьків, але 3 певних причин (матеріального, медичного чи соціального характеру) тимчасово в ньому знаходяться [5].

Закладом системи соціального захисту є будинок-інтернат, в якому постійно мешкають діти віком від 4 до 18 років, котрі мають різної складності фізіологічно-психологічні проблеми. У такому закладі, що розташований в с. Степове Миколаївського району, нараховується 49 підопічних.

Більшість дітей, котрі потребують соціального захисту, перебувають у спеціальних і санаторних школах-інтернатах (66\%) та в загальноосвітніх школах-інтернатах (27\%). Незначна кількість дітлахів знаходять притулок у будинку-дитини (2\%) і в будинкуінтернаті (1\%) (див. Рис. 2) [13].

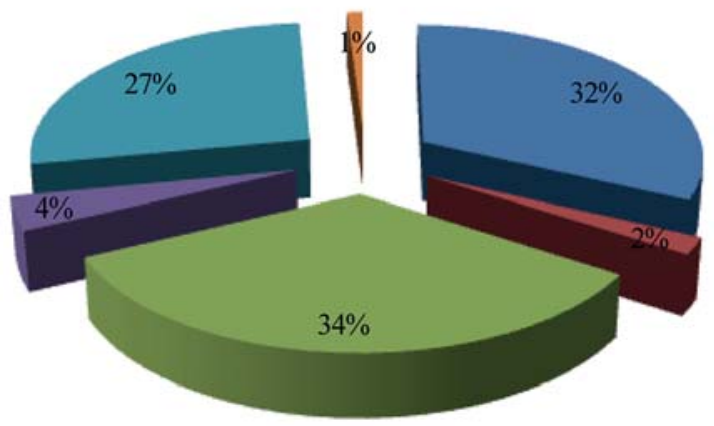

" спеціальна школаінтернат

ш будинок дитини

шанаторна школаінтернат

шентр соціальнопсихологічної реабілігації

шагальноосвітня школаінтернат

шудинок-інтернат

Pис. 2. Розподіл дітей за типами закладів по їх догляду в Миколаӥвській області у 2019 р. [13] 
«Public Administration and Regional Development» https://pard.mk.ua/index.php/journal

Якщо говорити про розподіл дітей за віком в інтернатних закладах, то у 2019 р. в Миколаївській області з-поміж 4676 дітей, що знаходилися у таких закладах: $1,4 \%$ - це діти віком 0-2 роки; $3,7 \%$ - 3-5 років; 41,3\% - 6-10 років; $44,8 \%$ - $11-15$ років; $8,4 \%$ - 16 17 років; 0,4\% - старше 18 років. Із наведених даних можна зробити висновок, що саме діти підліткового віку найбільше потребують соціального захисту та є менш затребуваними при усиновленні або при встановленні опіки чи піклування (див. Рис. 3) [13].

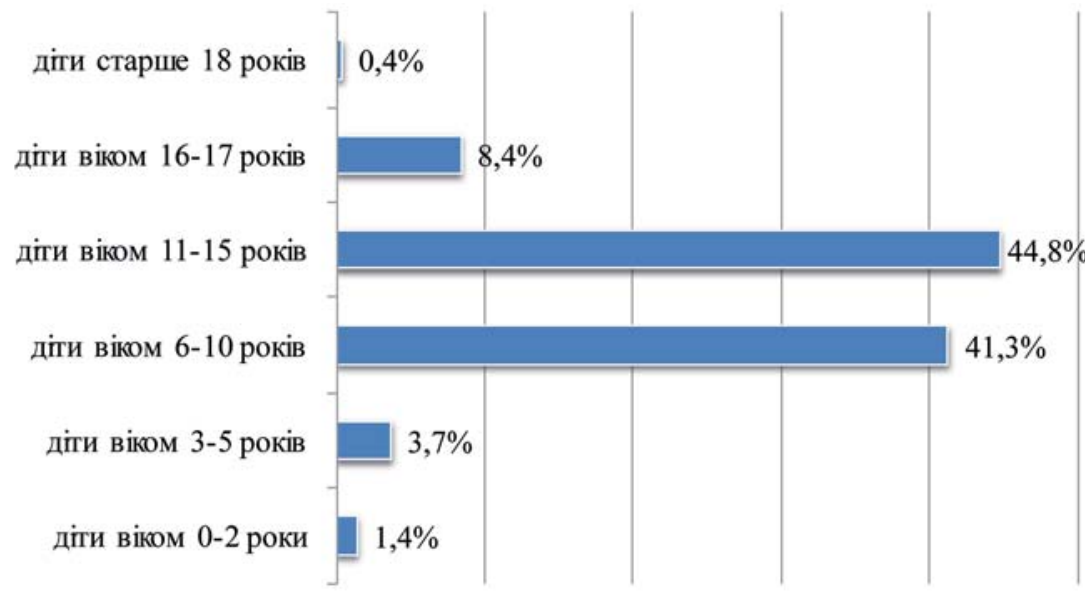

Puc. 3. Розподіл дітей за віком в інтернатних закладах Миколаӥвської області у 2019 р. [13]

У закладах по догляду за дітьми можливе перебування дітлахів цілодобово, вдень або за особливим графіком (індивідуальне навчання). Із загальної кількості дітей, які перебувають в інтернатних закладах, більше половини знаходяться цілодобово, $45 \%$ - відвідують відповідні заклади тільки у денний час та лише $2 \%$ дітей навчаються за індивідуальним графіком і мешкають удома. При цьому в середньому 38\% дітлахів живуть в інтернатних закладах від 1 до 3 років, 27\% - 4-6 років, 20\% - до 1 року, 13\% 7-9 років та 2\% - більше 10 років. У цілому 42\% дітей знаходяться в таких закладах понад три роки (див. Рис. 4) [13]. Інакше кажучи, 
кожна третя дитина перебуває в інтернаті від 3 до 10 і більше років. I найгірше те, що 3-поміж цих дітей, у 96\% є батьки. Такий показник $\epsilon$ результатом неякісної i недостатньої роботи 3 реінтеграції (повернення) дітлахів у власні родини. Тому, перш за все, необхідно надавати фахову соціально-психологічну допомогу тим сім'ям, котрі цього потребують, проводити дієві заходи по вихованню дітей у сімейному середовищі та їх адаптації в суспільстві.
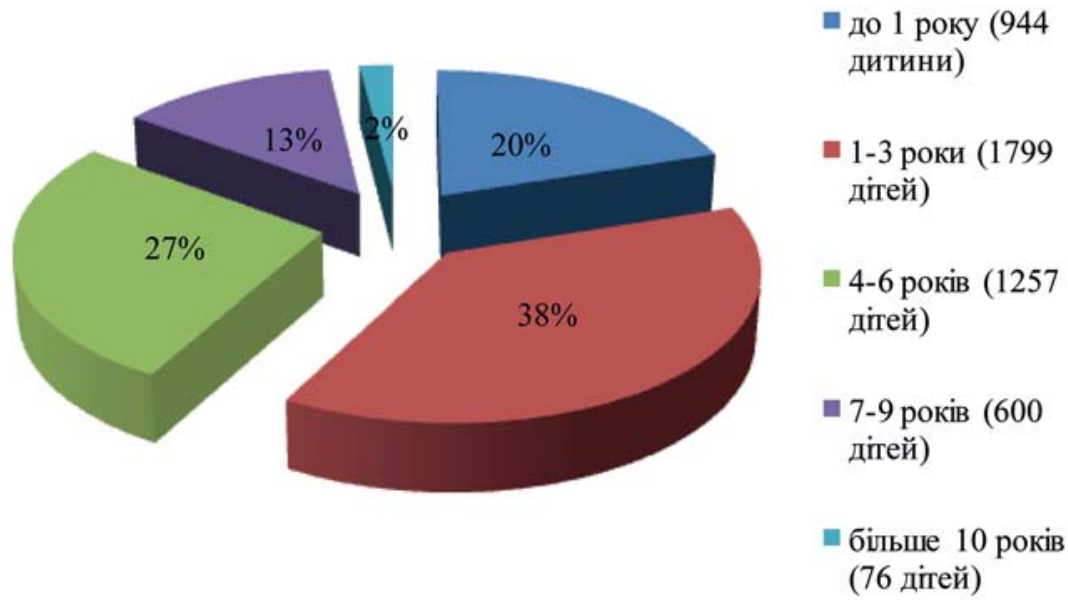

Pис. 4. Тривалість перебування дітей за віком в інтернатних закладах Миколаївської області у 2019 р. [13]

Окремо хотілося б зазначити, що на Миколаївщині в 2019 р. на обліку служб у справах дітей перебувало 800 дітей-сиріт та дітей, позбавлених батьківського піклування, котрі потенційно можуть бути усиновлені. Однак, переважна більшість 3 них є дітьми віком старше 10 років або мають складні проблеми зі здоров'ям чи порушенням розвитку, що ускладнює можливість їх усиновлення (оскільки майже всі кандидати в усиновителі прагнуть взяти в родину виключно здорову дитину дошкільного віку). Майже 500 дітей виховуються у прийомних сім'ях, дитячих будинках сімейного типу або перебувають під опікою чи піклуванням. 368 дітей 
«Public Administration and Regional Development»

https://pard.mk.ua/index.php/journal

знаходяться у закладах інституційного догляду та виховання дітей, 3 них 122 дитини мають опікунів, піклувальників, але навчаються в установах інституційного догляду та виховання дітей у зв'язку зі станом здоров'я (див. Рис. 5) [13]. Проте, на сучасному етапі, враховуючи інноваційні підходи до виховання дітей, саме усиновлення вважається пріоритетною і найбільш захищеною формою влаштування дітей-сиріт та дітей, позбавлених батьківського піклування. Тому зусилля місцевої влади вже не один рік направленні на створення таких умов, які були б сприятливими як для майбутніх усиновителів, так і для дітей, котрі потребують батьків, а також на вмотивування до усиновлення одразу кількох дітлахів (братів і сестер), а також дітей старшого віку. 3-поміж дітей-сиріт та дітей, позбавлених батьківського піклування в регіоні у 2018 р. знайшли нові родини лише 63 дитини, при цьому 40 дітей було усиновлено громадянами України та 23 дитини - іноземцями [13]. Враховуючи зазначені цифр можна говорити про зменшення кількості родин, які бажають створити прийомну сім'ю або дитячий будинок сімейного типу. Відповідно така ситуація потребує кардинальних і рішучих змін як з боку держави, так і з боку очільників області. Насамперед, необхідно активізувати роботу з населенням стосовно популяризації сімейних форм виховання дітей-сиріт та дітей, позбавлених батьківського піклування, наголошуючи на принципі збереження родинних зв'язків; фінансово-матеріально заохочувати до прийняття дітлахів у власні сім'ї; надавати різні соціальні пільги (наприклад, безкоштовне навчання у вищих начальних закладах чи спеціалізоване медичне обслуговування, відвідування культурно-пізнавальних заходів на безоплатній основі тощо).

На жаль, на обліку соціальних служб перебувають і ті діти, котрі мають батьків та мешкають разом із ними, але опинилися у складних життєвих обставинах. Таких сімей в Миколаївській області наприкінці 2018 р. нараховувалось 5925. Переважно це сім’і, в яких батьки ведуть нездоровий спосіб життя, зловживають алкогольними напоями або вживають наркотичні засоби, здійснюють насилля над дітьми (у 2018 р. 145 дітей стали жертвами жорстокого поводження із ними з боку дорослих), а також неналежним чином виконують свої 638 Isue DOI: 10.34132/pard 


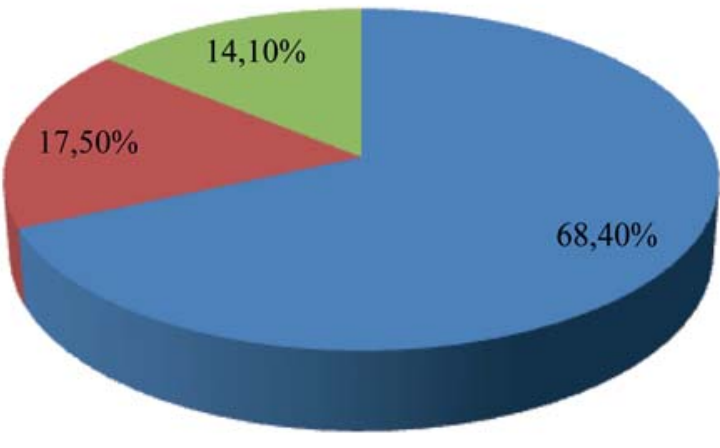

\section{прийомні сім'ї, дитячі будинки сімейного типу чи опіка та піклування}

заклади інституційного догляду та виховання дітей

поза сімейним оточенням

Pис. 5. Розподіл дітей-сиріт, дітей позбавлених батьківського піклування за відповідними формами їх влаштування в Миколаївській області у 2019 р. [13]

обов'язки 3 виховання та догляду за дітьми. Найбільшу кількість дітлахів, які опинилися у складних життєвих обставинах зафіксовано в службах у справах дітей Снігурівської (160 дітей), Новоодеської (141 дитина), Первомайської (121 дитина), Баштанської (113 дітей) районної державної адміністрацій та Миколаївської місцевих рад (134 дитини) [13]. Найгірше те, що такі діти частіше за інших скоюють правопорушення різної тяжкості (крадіжка, хуліганство, нанесення тілесних ушкоджень) або стають жертвами злочинів (наприклад, втягування у зловживання наркотичних засобів чи алкогольних напоїв або зайняття проституцією). Однак, реальні масштаби цих проблем в області невідомі, тому потрібно проводити грунтовні дослідження, приділяти особливу увагу дітям iз боку батьків, вчителів, інших дорослих з метою своєчасного їх виявлення, а також надавати відповідну фахову допомогу родинам, котрі ii потребують. I хоча в Миколаївській області, як і в інших регіонах країни ведеться активна робота 3 надання соціально- 
«Public Administration and Regional Development»

https://pard.mk.ua/index.php/journal

економічної i психологічної допомоги таким сім'ям. Але всі впроваджуванні заходи $\epsilon$ недостатньо ефективними, про що свідчить значна кількість справ про позбавлення батьківських прав та про відібрання дітей у батьків у зв'язку із загрозою їх життю і здоров'ю. Лише протягом 2018 р. органами опіки та піклування до судів було подано 180 позовів про позбавлення батьківських прав (із них 150 задоволено) та 54 позови про відібрання дітей у батьків без позбавлення їх батьківських прав (із них 36 задоволено); 90 дітей були відібрані у батьків за рішенням органів опіки та піклування у зв'язку із безпосередньою загрозою їх життю і здоров'ю (найбільше таких рішень було прийнято в м. Миколаєві - 30 дітей та Баштанському районі - 13 дітей) [13].

Окрім того, в Миколаївській області мешкає майже 6 тис. сімей, в яких виховуються діти 3 інвалідністю, і близько 7 тис. сімей, в котрих один або обидва із батьків мають ту чи іншу групу інвалідності [13]. Такі родини потребують не тільки матеріальної допомоги, а i соціального супроводу, що повинен включати всі аспекти моральнопсихологічної підтримки, реабілітації, адаптації, захисту дитини та підвищення ресурсу власних можливостей батьків для нормального догляду і виховання дітей. Адже проблеми, з якими стикаються ці сім'ї є набагато ширшими, ніж виключно складне матеріальне становище. Тому питання соціальної підтримки i допомоги зазначеним родинам вимагають грунтовного і комплексного підходу в їх вирішенні.

На кінець хотілося б звернути увагу на рівень фінансового забезпечення закладів по догляду за дітьми Миколаївської області. Згідно із чинним законодавством джерелами фінансування таких закладів є державний і обласний бюджети, спонсорська чи благодійна допомога. За підсумками 2017 р. і 2018 р. фінансування із обласного бюджету займало вагоме місце у матеріально-грошовому забезпеченні закладів по догляду за дітьми, при цьому спостерігалося значне його зростання. Натомість об'єми спонсорської і благодійної допомоги за один рік зменшилися більше ніж удвічі. Всього фінансове забезпечення таких закладів у 2017 р. становило понад 376 млн грн., у 2018 р. - майже 520,6 млн грн. (див. Та640 Isue DOI: $10.34132 /$ pard 
Соціальний захист дитинства в Украӥні: нормативно-правове забезпечення та сучасний стан (на прикладі Миколаївської області)

блиця 2) [13]. Та не зважаючи на збільшення обсягів фінансування поліпшення якості догляду за дітьми не спостерігається (необхідно розуміти, що різницею збільшення фінансування $\epsilon$ виключно різниця у підвищенні розмірів заробітної плати та зростанні цін на товари і послуги за минулі роки). У 2018 р. на забезпечення потреб дитини (харчування, лікування тощо) було витрачено лише 16,3\% від загальної суми фінансування (59,7 млн грн). При цьому, в залежності від типу інтернатного закладу, різниться об'єм витрат на одну дитину в місяць - від 5183 грн (санаторна школа-інтернат) до 18437 грн (обласний будинок дитини). В середньому витрати на одну таку особу становлять близько 11033 грн в місяць, що на 21\% більше ніж у 2017 р. [13].

Таблиця 2

\section{Фінансове забезпечення закладів по догляду за дітьми в Миколаївській області}

\begin{tabular}{|c|c|c|c|}
\hline Рік & $\begin{array}{c}\text { Державний } \\
\text { бюджет (грн) }\end{array}$ & $\begin{array}{c}\text { Опонсорська } \\
\text { бюджет (грн) } \\
\text { та благодійна } \\
\text { допомога } \\
\text { (грн) }\end{array}$ \\
\hline 2017 р. & 155279444 & 210497640 & 10372117 \\
\hline 2018 р. & 201522800 & 314313482 & 4716685 \\
\hline
\end{tabular}

Якщо говорити про витрати на утримання інтернатних закладів, то в загальній їх сумі найбільшу частку становить оплата праці персоналу (68\%), а найменшу - капітальні видатки $(2 \%)$ та видатки на одяг, взуття і медикаменти вихованцям $(2 \%)$ (див. Рис. 6). Варто відзначити, що в 2018 р., у порівнянні 3 2017 р., приблизно на 7\% скоротилися витрати на капітальні ремонти, придбання обладнання і предметів довгострокового користування. Витрати на харчування дітей навпаки збільшилися у 2018 р. майже на 3 млн грн у порівнянні з 2017 р. Збільшилися витрати і на одяг та взуття для підопічних інтернатних закладів (приблизно на 743 тис. грн.). Стабільно незначними за два роки $є$ витрати на медикаменти для дітей (близько 1\%) [13]. 


\section{- оплата праці}
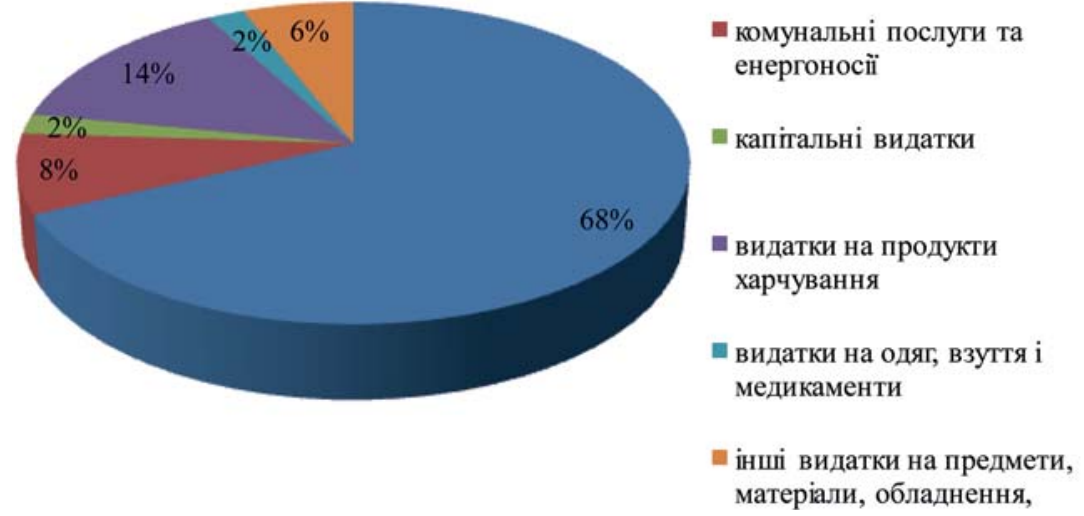

Pис. 6. Витрати на утримання закладів по догляду за дітьми Миколаӥвської області в 2018 р. [13]

Враховуючи вищевикладене можна узагальнити, що наразі завершується I етап виконання Національної стратегії реформування системи інституційного догляду та виховання дітей на 2017-2026 роки, що має на меті запровадження змін у системі захисту дитинства, орієнтованих передусім на збереження та підтримку сім’ї, якнайкраще забезпечення прав та інтересів дитини. I хоча діяльність закладів по догляду за дітьми однаково спрямована на забезпечення нормальної їх життєдіяльності, у вітчизняному інституційному забезпеченні соціального захисту дитинства (на прикладі, Миколаївській області) можна виокремити ряд проблем. По-перше, це перевантаженість закладів по догляду за дітьми кількістю вихованців, через що основна робота працівників спрямована на фізіологічний догляд дітей, а не на їх нормальний психологічний розвиток та подальшу соціальну адаптацію як в родині, так і в суспільстві. Як наслідок, у таких дітлахів (особливо, віком до 3 років) спостерігається порушення сну, зниження ваги i непропорційний фізичний розвиток, затримка розвитку мовлення та навичок дій з різними предметами. Вважаємо, що перебування дітей 
в родинах усуне зазначені проблеми та буде сприяти покращенню їх психологічного і фізичного здоров'я. По-друге, нерівномірне територіальне розташування відповідних закладів (у самому м. Миколаєві знаходяться 11 закладів, в інших містах регіону розташовано 6 закладів, у сільській місцевості - 11 закладів) та значна віддаленість окремих із них від обласного і районних центрів. До речі, така картина спостерігається і в інших регіонах України. По-третє, нераціональне використання приміщень і коштів на їх утримання (67\% дітей перебувають у закладах за рахунок держави і $33 \%$ частково або повністю утримуються за рахунок батьків). По-четверте, неякісне кадрове забезпечення органів публічної влади, до компетенції яких входять питання охорони дитинства та закладів по догляду за дітьми (плинність кадрів, незначний розмір заробітної плати працівників, надмірне навантаження на спеціалістів, відсутність системи професійно-посадового просування та якісної фахової підготовки публічних службовців тощо). Окрім того, на території області відсутня розвинена мережа центрів догляду за дітьми, оздоровчих та інших установ для дітлахів зі складними, комплексними порушеннями розвитку; немає таких послуг як особистий (персональний) асистент, послуга перепочинку, мобільні реабілітаційні бригади, послуга раннього втручання та ін.

3 метою усунення окреслених проблем та попередження виникнення інших необхідно:

- удосконалити вітчизняне законодавство у сфері соціального захисту дитинства враховуючи відповідні міжнародно-правові документи та позитивний європейський досвід;

- залучати батьків та територіальні громади до відшкодування витрат на утримання дітлахів у закладах по догляду за ними. Вважаємо, що такий крок змусить батьків реально оцінювати потребу у перебуванні дитини в інтернатах, а владних представників територіальних громад - взяти на себе відповідальність за своїх неповнолітніх мешканців, співпрацювати з батьками, запроваджувати необхідні послуги на місцях;

- розробити стандарт оцінювання роботи органів опіки та піклування із передбаченням відповідальності голів відповідних ISSN 2616-6216. Publ. upr. reg. rozvit. 2020, 8: 618-653 643 
«Public Administration and Regional Development»

https://pard.mk.ua/index.php/journal

органів за невжиття заходів щодо влаштування дитини-сироти $\mathrm{i}$ дитини, позбавленої батьківського піклування до сімейних й інших форм виховання, наближених до сімейних;

- організувати гарячі сніданки та обіди в школах як підтримку малозабезпеченим родинам, оскільки частіш за все батьки наважуються віддати дитину до інтернату через те, що не спроможні забезпечити їі належним харчуванням;

- упорядкувати діяльність груп подовженого дня в закладах освіти, організувати роботу різних гуртків на безоплатній основі, що дозволить зменшити відсоток інтернатних дітей, батьки яких через графік роботи чи інші обставини не можуть забирати їх удень;

- налагодити процес підвезення дітей до освітніх закладів (шкільний автобус, послуга соціального таксі тощо), що дасть їх змогу щоденно відвідувати такі заклади та повертатися додому;

- запровадити послугу раннього втручання, що дозволить батькам iз дитиною від народження до 4-х років, яка має інвалідність, порушення розвитку чи ризик їх виникнення, постійно перебувати разом із малюком та безпосередньо брати участь у реабілітаційних заходах для нього, а також набути навичок, необхідних для забезпечення кращих умов для збереження здоров'я дитини та фізичного і психологічного іiі розвитку;

- зобов'язати органи публічної влади, громадськість та самих батьків здійснювати усі можливі кроки по відновленню функцій сімей, які через соціально-економічні, соціально-психологічні та інші негаразди, розгублені, втратили або ненавчені навичкам організації побуту, створення умов для самих себе та власних дітей;

- впровадити дієву систему підготовки дітей і молоді до сімейного життя та відповідального батьківства $з$ урахуванням моральних засад і традиційних цінностей українського суспільства;

- налагодити комплексну і конструктивну співпрацю служб у справах дітей із органами соціальної політики, правоохоронними органами, закладами освіти й охорони здоров'я, недержавними організаціями і громадянами у сфері соціального захисту дитинства, що покращить якість і підвищить рівень легітимності відповідних 644 Isue DOI: $10.34132 /$ pard 
управлінських рішень, запобіжить зловживанню владою і службовим становищем тощо;

- покращити існуючий стан кадрового забезпечення органів публічної влади з питань соціального захисту дітей та відповідних закладів по догляду за ними (підвищити спеціалістам заробітну плату; затвердити відсутній наразі показник щодо визначення кількісного складу сектору/відділу захисту прав, свобод та законних інтересів дітей служб у справах дітей; розробити та затвердити типову програму навчання для новопризначених фахівців та плани їх стажування; забезпечити перенавчання та перекваліфікацію спеціалістів у випадку реорганізації, реформування відповідних установ і закладів тощо).

Вважаємо, що комплексна реалізація зазначених заходів сприятиме координації і спрямуванню дій усіх суб'єктів соціальної роботи на раннє виявлення сімейного неблагополуччя, надання родинам із дітьми комплексної підтримки і допомоги в подоланні складних життєвих обставин.

Висновки. На сьогодні немає єдиного наукового підходу до розуміння поняття «соціальний захист дитинства», на законодавчому рівні воно також не знайшло свого відображення. Найбільш загально цей термін можна охарактеризувати як діяльність держави, спрямовану на забезпечення процесу формування i розвитку повноцінної особистості дитини (особа, яка не досягла 18 років), виявлення і нейтралізацію негативних факторів, що впливають на iii індивідуальність, створення належних умов для нормального іiі самовизначення й утвердження у житті.

В Україні, 3 перших років іï незалежності, значна увага приділяється соціально-економічному і правовому захисту дітей. За минулі роки створено низьку публічно-владних інституцій щодо соціального захисту дитинства, прийнято ряд важливих законодавчих документів, ратифіковано відповідні міжнародні нормативноправові акти, розроблено і впроваджено не один десяток спеціальних державних і регіональних програм по охороні дитинства. Зокрема, у досліджуваній сфері досягнуто певного прогресу: підвищено розмір державної допомоги при народженні дитини; запроваджено ISSN 2616-6216. Publ. upr. reg. rozvit. 2020, 8: 618-653 645 
«Public Administration and Regional Development»

https://pard.mk.ua/index.php/journal

державну допомогу при усиновленні дитини; створено єдину базу даних дітей сиріт та дітей, позбавлених батьківського піклування та усунуто дискримінацію у фінансуванні утримання таких дітей залежно від форми влаштування; визначено порядок провадження органами опіки та піклування діяльності, пов'язаної із захистом прав дитини; запроваджено правовий інститут Уповноваженого Президента України з прав дитини; вживаються суттєві заходи по запровадженню проактивної соціальної політики стосовно родин, які виховують дітей; змінено методики виховання у закладах по догляду за дітьми тощо. Вперше за роки незалежності нашої держави питання забезпечення житлом дітей-сиріт та дітей, позбавлених батьківського піклування почало вирішуватися системно та ефективно. Як наслідок, вжиті заходи дозволили зменшити кількість безпритульних дітей, активізувати усиновлення дітлахів.

Однак, незважаючи на все це, українське законодавство у сфері соціального захисту дитинства залишається декларативним та не в повній мірі охоплює величезне розмаїття конкретних життєвих ситуацій, які виникають при виконанні державними службовцями та посадовими особами органів місцевого самоврядування своїх обов'язків із захисту прав дітей. Окрім того, в державі відсутній системний підхід до врахування думки дитини на всіх рівнях суспільного життя. Тому, ми вважаємо, що для України залишається серйозним питанням практичної реалізації рекомендацій, які надаються моніторинговими структурами ООН та Ради Європи. На цю проблему має реагувати не лише Міністерство соціальної політики України, але й уряд країни, відповідні центральні органи виконавчої влади, обласні та районні місцеві державні адміністрації, органи місцевого самоврядування, Генеральна прокуратура України, представники судової влади, а також Президент та народні депутати України. Проте, саме комплексне впровадження необхідних заходів сприятиме вирішенню проблем у сфері соціального захисту дитинства в Україні та в Миколаївській області, зокрема.

\section{Стаття надійшла до редакції: 27.01.20}




\section{SOCIAL PROTECTION OF CHILDHOOD IN UKRAINE: LEGAL PROVISION AND CURRENT STATE (ON THE EXAMPLE OF MYKOLAIV REGION)}

Anastasia Shulga, PhD in Public Administration, Senior Lecturer, Institute of Public Administration, Petro Mohyla Black Sea National University, Mykolaiv, Ukraine

Natalia Surina, Service for Children of the Mykolayiv Regional State Administration, Mykolaiv, Ukraine.

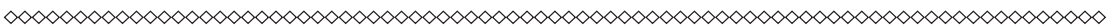

The article is analyzes the legal support of social protection of childhood in Ukraine, outlines its current state (on the example of the Mykolaiv region), the existing problems in the researched sphere are revealed and the ways of their solution are offered. At the beginning of the study, the essence of the concept of «social protection» and «social protection of childhood» is defined. Different views of scientists on the interpretation of these two concepts are given. The main part of the article is devoted to characterizing the formation of the system of social protection of childhood and its legal support. During the years of Ukraine's independence, a number of international normative legal acts have been ratified, vector laws and other legal documents have been adopted, and the best foreign experience of developed countries in building a modern national child protection system has been studied and applied. Significant measures have also been taken to introduce a proactive social policy in the country with regard to families raising children. Currently the domestic system of social protection of children does not meet all the needs of the population and does not fully fulfill its obligations aimed at ensuring social and legal guarantees of children's rights. The system of institutions of institutional care and upbringing of children is analyzed, and also distribution of children on age, on term of stay in institutions on their care in the Mykolaiv area, etc. is investigated. It has been established that deinstitutionalization aims to 
«Public Administration and Regional Development»

https://pard.mk.ua/index.php/journal

introduce changes in the system of child protection, focused primarily on the preservation and support of the family, the best possible protection of the rights and interests of children. Such a policy is a condition for reforms aimed at reducing the level of orphanhood in the country. At the end of the article, it was concluded that comprehensive implementation of the measures will help solve existing problems in the domestic system of social protection of children, coordination and direction actions of all subjects of social work on early detection of family problems, providing families with children comprehensive support and assistance in overcoming difficult life circumstances.

Keywords: social protection of childhood, social service, boarding school, institutional care, difficult life circumstances.

\section{Received: 27.01 .20}

\section{References}

1. Abalkyna, L.Y. (1999). Ékonomycheskaya éntsyklopedyya [Economic Encyclopedia]. Moskva: Ekonomika [in Russian].

2. Bolotina, N.I. (2000). Pravo lyudyny na sotsial'ne zabezpechennya v Ukrayini: problema terminiv i ponyat' [Human right to social security in Ukraine: the problem of terms and concepts]. Pravo Ukrayiny, 4, 37-39 [in Ukrainian].

3. Introduction on the Social Security (1984). (n.d.). Retrieved from http://ezinearticles.com/?Introduction-To-Social-Security-Benefits\&id=732964 [in English].

4. Khaplanova, YE.M. (2008). Do vyznachennya ponyattya «sotsial'nyy zakhyst osib pokhyloho viku» [To define the concept of «social protection of the elderly»]. Forum of Law: Electron. Science. specialties type, 1, 434-438 [in Ukrainian].

5. KNP «Mykolayivs'kyy oblasnyy budynok dytyny» Mykolayivs'koyi oblasnoyi rady [MNE «Mykolayiv Regional Orphanage» of the Mykolayiv Regional Council]. Retrieved from http://oblzdrav.mk.gov.ua/index.php/ oblasni-94931/budinok-ditini [in Ukrainian]. 
Соціальний захист дитинства в Україні: нормативно-правове забезпечення та сучасний стан (на прикладі Миколаївської області)

6. Konstytutsiya Ukrayiny pryiniata 28 chervnya 1996 roku № 254k/96VR [Constitution of Ukraine from June 28 1996, № 254k/96-VR]. zakon.rada. gov.ua. Retrieved from https://zakon.rada.gov.ua/laws/show/254\%D0\%BA/96$\% \mathrm{D} 0 \% \mathrm{~B} 2 \% \mathrm{D} 1 \% 80$ [in Ukrainian].

7. Kravchenko, M.V. (2017). Derzhavna polityka v sferi zakhystu prav ta blahopoluchchya ditey: retrospektyvnyy analiz [State policy in the field of protection of the rights and welfare of children: a retrospective analysis]. Derzhavne upravlinnya: udoskonalennya ta rozvytok, 3. Retrieved from http:// www.dy.nayka.com.ua/?op=1\&z=1048 [in Ukrainian].

8. Machul'skaya, E.E., Horbacheva, ZH.A. (2017). Pravo sotsyal'noho obespechenyya [The right of social security]. Moskva: Yzdatel'stvo Yurayt [in Russian].

9. Makarenko, A.C. (1954). Deyaki vysnovky z pedahohichnoho dosvidu [Some conclusions from the pedagogical experience]. Kyyiv: Rad. shk. [in Ukrainian].

10. Perrin, G. (1988). A hundred years of social insurance. Labor and Society, 9, 399-402 [in English].

11. Reytynh rehioniv Ukrayiny za rivnem instytutsializatsiyi ditey stanom na 31 hrudnya 2018 roky [Rating of regions of Ukraine by the level of institutionalization of children as of December 31, 2018]. (n.d.). diplatform.org. ua. Retrieved from http://diplatform.org.ua/ [in Ukrainian].

12. Rozporyadzhennya Kabinetu Ministriv Ukrayiny Pro Natsional'nu stratehiyu reformuvannya systemy instytutsiynoho dohlyadu ta vykhovannya ditey na 2017-2026 roky ta plan zakhodiv z realizatsiyi yiyi I etapu pryiniatyi 9 serpnya 2017 roku № 526-r. [Order of the Cabinet of Ministers of Ukraine On the National Strategy for Reforming the System of Institutional Care and Upbringing of Children for 2017-2026 and the Action Plan for the Implementation of its First Stage from August 9, 2017, № 526-r]. zakon.rada.gov.ua. Retrieved from https://zakon.rada.gov.ua/laws/show/526-2017-\%D1\%80 [in Ukrainian].

13. Rozporyadzhennya Mykolayivs'koyi oblasnoyi derzhavnoyi administratsiyi Proekt Rehional'noho stratehichnoho planu diy z reformuvannya systemy instytutsiynoho dohlyadu ta vykhovannya ditey v Mykolayivs'kiy oblasti na 2019-2029 roky pryiniatyi 21 serpnya 2019 roku № 403-r. [The order of the Nikolaev regional public administration The project of the Regional strategic plan of actions on reforming of system of institutional care and education of 
«Public Administration and Regional Development»

https://pard.mk.ua/index.php/journal

children in the Nikolaev area for 2019-2029 from August 21, 2019, № 403-r]. mk.gov.ua. Retrieved from http://www.mk.gov.ua/ua/oda/order/?doc_id=16507 [in Ukrainian].

14. Shaykhatdynov, V.SH. (2012). Pravo sotsyal'noho obespechenyya v Rossyy [Social security law in Russia]. Moskva: Izdatel'stvo Yurayt [in Russian].

15. Sukhomlyns'kyy, V.O. (1976). Yak vykhovaty spravzhnyu lyudynu [How to bring up a real person]. (Volume 2). Kyyiv: Rad. school [in Ukrainian].

16. Syrota, Y.M. (2004). Pravo sotsyal'noho obespechenyya v Ukrayne [The right of social security in Ukraine]. Kharkiv: Odyssey [in Ukrainian].

17. Systema instytutsiynoho dohlyadu ta vykhovannya ditey ta perspektyvy yiyi reformuvannya [The system of institutional care and education of children and prospects for its reform] (n.d.). Retrieved fromhttps://www. president.gov.ua/storage/j-files-storage/00/54/22/7dc6bb44de47d7096d1306c4c5169c07_1512986280.pdf [in Ukrainian].

18. The Encyclopedia Americana (1973). (Vol. 25.). New York (n.d.) [in English].

19. Ukaz Prezydenta Ukrayiny Pro natsional'nu prohramu «Dity Ukrayiny» pryiniatyi vid 18 sichnya 1996 roku № 63/96 [Decree of the President of Ukraine On the national program «Children of Ukraine» from January 18, 1996, № 63/96]. zakon.rada.gov.ua. Retrieved from https://zakon.rada.gov.ua/laws/ show/63/96 [in Ukrainian].

20. Ukaz Prezydenta Ukrayiny Pro Natsional'nu stratehiyu profilaktyky sotsial'noho syrit·stva na period do 2020 roku pryiniatyi 22 zhovtnya 2012 roku № 609/2012 [Decree of the President of Ukraine On the National Strategy for the Prevention of Social Orphanhood until 2020 from October 22, 2012, № 609/2012]. zakon.rada.gov.ua. Retrieved from https://zakon.rada.gov.ua/laws/ show/609/2012 [in Ukrainian].

21. Ukaz Prezydenta Ukrayiny Pro pershocherhovi zakhody shchodo zakhystu prav ditey pryiniatyi 11 lypnya 2005 roku № 1086/2005 [Decree of the President of Ukraine On priority measures to protect the rights of children from July 11, 2005, № 1086/2005]. zakon.rada.gov.ua. Retrieved from https://zakon. rada.gov.ua/laws/show/1086/2005 [in Ukrainian].

22. Ukaz Prezydenta Ukrayiny Pytannya Upovnovazhenoho Prezydenta Ukrayiny z prav dytyny pryiniatyi 11 serpnya 2011 roku № 811/2011 [Decree of the President of Ukraine Questions of the Commissioner of the President of 
Соціальний захист дитинства в Украӥні: нормативно-правове забезпечення та сучасний стан (на прикладі Миколаївської області)

Ukraine for the Rights of the Child from August 11, 2011, № 811/2011]. zakon. rada.gov.ua. Retrieved from https://zakon.rada.gov.ua/laws/show/811/2011 [in Ukrainian].

23. Volynets', L.S. (1998). Sotsial'nyy zakhyst ditey syrit i ditey, pozbavlenykh bat'kivs'koho pikluvannya [Social protection of orphans and children deprived of parental care]. Kyyiv: [b. v.] [in Ukrainian].

24. Zakon Ukrayiny Pro okhoronu dytynstva pryiniatyi 26 kvitnya 2001 roku № 2402-III [Law of Ukraine On the protection of childhood from April 26, 2001, № 2402-III]. zakon.rada.gov.ua. Retrieved from https://zakon.rada.gov. ua/laws/show/2402-14 [in Ukrainian].

25. Zakon Ukrayiny Pro orhany i sluzhby u spravakh ditey ta spetsial'ni ustanovy dlya ditey pryiniatyi 24 sichnya 1995 roku № 20/95-VR [Law of Ukraine On bodies and services for children and special institutions for children from January 24, 1995, № 20/95-VR]. zakon.rada.gov.ua. Retrieved from https://zakon.rada.gov.ua/laws/show/20/95-\%D0\%B2\%D1\%80 [in Ukrainian].

26. Zakon Ukrayiny Pro osnovy sotsial'noho zakhystu bezdomnykh osib i bezprytul'nykh ditey pryiniatyi 2 chervnya 2005 roku № 2623-IV [Law of Ukraine On the basics of social protection of homeless people and homeless children from June 2, 2005, № 2623-IV]. zakon.rada.gov.ua. Retrieved from https://zakon.rada.gov.ua/laws/show/2623-15 [in Ukrainian].

27. Zakon Ukrayiny Pro poperedzhennya nasyl'stva v sim"yi pryiniatyi 15 lystopada 2001 roku № 2789-III [Law of Ukraine On the prevention of domestic violence from November 15, 2001, № 2789-III]. zakon.rada.gov.ua. Retrieved from https://zakon.rada.gov.ua/laws/show/2789-14 [in Ukrainian].

28. Zakon Ukrayiny Pro sotsial'nu robotu z sim"yamy, dit'my ta moloddyu pryiniatyi 26 chervnya 2001 roku № 2558-III [Law of Ukraine On social work with families, children and youth from June 26, 2001, № 2558-III]. zakon. rada.gov.ua. Retrieved from https://zakon.rada.gov.ua/laws/show/2558-14 [in Ukrainian].

29. Zakon Ukrayiny Pro sotsial'nyy i pravovyy zakhyst viys'kovosluzhbovtsiv ta chleniv yikh simey pryiniatyi 20 hrudnya 1991 roku № 2011-XII [Law of Ukraine On social and legal protection of servicemen and members of their families from December 20, 1991, № 2011-XII]. zakon. rada.gov.ua. Retrieved from https://zakon.rada.gov.ua/laws/show/2011-12 [in Ukrainian]. 
«Public Administration and Regional Development» https://pard.mk.ua/index.php/journal

30. Zakon Ukrayiny Pro zabezpechennya orhanizatsiyno-pravovykh umov sotsial'noho zakhystu ditey-syrit ta ditey, pozbavlenykh bat'kivs'koho pikluvannya pryiniatyi 13 sichnya 2005 roku № 2342-IV [Law of Ukraine On ensuring the organizational and legal conditions of social protection of orphans and children deprived of parental care from January 13, 2005, № 2342-IV]. zakon.rada.gov.ua. Retrieved from https://zakon.rada.gov.ua/laws/show/234215 [in Ukrainian].

31. Zakon Ukrayiny Pro zahal'noderzhavnu prohramu «Natsional'nyy plan diy shchodo realizatsiyi Konventsiyi OON pro prava dytyny» na period do 2016 roku pryiniatyi 5 bereznya 2009 roku № 1065-VI [Law of Ukraine On the national program «National Action Plan for the Implementation of the UN Convention on the Rights of the Child» for the period up to 2016 from March 5, 2009, № 1065-VI]. zakon.rada.gov.ua. Retrieved from https://zakon.rada.gov. ua/laws/show/1065-17 [in Ukrainian].

32. Zakon Ukrayiny Pro zapobihannya ta protydiyu domashn'omu nasyl'stvu pryiniatyi 7 hrudnya 2017 roku № 2229-VIII [Law of Ukraine On prevention and counteraction to domestic violence from December 7, 2017, № 2229-VIII]. zakon.rada.gov.ua. Retrieved from https://zakon.rada.gov.ua/laws/ show/2229-19 [in Ukrainian].

33. Zakon Ukrayiny Simeynyy kodeks Ukrayiny pryiniatyi 10 sichnya 2002 roky № 2947-III [Law of Ukraine Family Code of Ukraine from January 10, 2002, № 2947-III]. zakon.rada.gov.ua. Retrieved from https://zakon.rada. gov.ua/laws/show/2947-14 [in Ukrainian].

\section{Відомості про авторів / Information about the Authors}

Шульга Анастасія Алімівна: Чорноморський національний університет імені Петра Могили: вул. 68 Десантників 10, Миколаїв, 54003, Україна

Anastasia Shulga: Petro Mohyla Black Sea National University: 68 Desantnykiv str. 10, Mykolaiv, 54003, Ukraine. 
ORCID. ORG./ 0000-0002-8528-8722

\author{
E-mail: ondain2009@ukr.net
}

Суріна Наталія Анатоліївна: Служба у справах дітей Миколаївської обласної державної адміністрації: вул. Наваринська 16, Миколаїв, 54030, Україна

Natalia Surina: Service for Children of the Mykolayiv Regional State Administration: Navarynska st. 16, Mykolaiv, 54030, Ukraine.

\title{
E-mail: natalkasurina@gmail.com
}

